\title{
Measuring the Effectiveness of Zakat Distribution (Case Study of Payment Behavior of Nomads in Sorong, West Papua, Indonesia)
}

Hamzah

Islamic Economic and Business Faculty (FEBI), Islamic State University (UIN) Alauddin Makassar, Indonesia Email: hamzahkhaeriyah@yahoo.co.id

Doi:10.5901/mjss.2016.v7n3p265

\section{Abstract}

Zakat is one of the social financial sources in Islamic Economics. One of society segment lived in Sorong city, West Papua, Indonesia, is Moslem nomads, which is in this study, categorized as Muzzaki. They have contributed to the BAZNAS (Badan Zakat Nasional) Sorong city. Nevertheless, they still opt to choose the distribution of the fund, either they want to distribute to their origin or Sorong (as they aee work there). The determination of distribution location is a part of their behavior. The main problem proposed in this study is to define whether the behaviors in determine the location of distribution is well justiced. If this behavior accomplished the sense of justice it is supposed support the collection of Zakat in Sorong city. Data presented are collected from the quoestionaire and interviews. Respondents' backgrounds are variety and they have competency in zakat field. This study is using Islamic Economic Theory approach. Conjunction with the purpose of this study, to measure the sense of justice we use theory construct modeling. We found that from the aspect of their action related to the duty of Zakat in Sorong city is supporting the justice of zakat distribution. Nonetheless, the score of minimum is $62.06 \%$ and maximum score is $74.13 \%$, which is less fair.

Keywords: Nomads' zakat behavior, justice redistribution of income

\section{Introduction}

The definition of nomads is a member of a people having no permanent abode, and who travel from place to place in order to find the fittest living at their own terms. Other terms of nomads are traveler, migrant or wanderer, they do not stay long in the same place. Mostly they journey is in order to find a better income. These people doing their economy activities in their new place as the origin become a memory. Their families stay at their origin, but they keep nomads to make their sustenance. Other than characteristic, their new place is become their living place and to earn living.

Sorong City is located in Papua Island and its position is in East Indonesia. Papua has multi etnic, religion and culture characteristics and categorized as nomads region. Generally, the native in Sorong City including Papua is often refereed as local tribe. They are from multi etnics, while bugis, buton, Makassar or often called (BBM), and javanesse, Madura and other classified as the migratory. The nomad has been doing social economy activities, hence by certain common sense, Sorong city, economically dominated by the nomads. The other way around, politic and government sectors are dominated by the natives.

Many nomads in Sorong city are Moslem. Therefore, they are required to fulfill their duties on Zakat. Zakat in Islam has two types; zakat fitrah (self purification) and zakat mal (wealth/income purification). Refer to as (Sarkhasiy w:1062 M), zakat mal is when one (Moslem) has to purify his wealth by paying his prescribed amount of zakat.

As a Moslem nomaden who are still have an emotional connection with their origin, it is important to study their behavior regarding their behavior in their own zakat distribution. Question arised, is the origin background affected the chances of akat distribution in their origin or they prefer to pay their zakat through BAZNAS at Sorong city? Refer to BAZNAS Sorong, zakat fund that has been collected at Sorong are still low compared to Umat' potential fund. Below is Zakat property in Sorong City during 2013-2014:

Table 1: Zakat, Infaq, Shadaqah UPZ in Sorong

\begin{tabular}{|l|l|c|c|c|c|c|c|c|c|}
\hline No & Types & Rice 2012 & $\mathbf{2 0 1 3}$ & $\mathbf{2 0 1 4}$ & $\mathbf{2 0 1 2}$ Money & $\mathbf{2 0 1 3}$ & $(\mathbf{\%})$ & $\mathbf{2 0 1 4}$ & $(\mathbf{\%})$ \\
\hline 01 & Zakat Fitrah & 18.589 & 19.730 & 4.668 & 591.094 .800 & 699.119 .500 & 18.28 & 773.585 .000 & 10.65 \\
\hline 02 & Zakat Mal & 0 & 0 & 0 & $211,835.500$ & 216.007 .000 & 1.97 & 288.851 .500 & 33.72 \\
\hline 03 & Infak/ Sadakah & 0 & 0 & 0 & 140.100 .000 & $152,699.000$ & 8.99 & 209.431 .000 & 37.15 \\
\hline & Total & 18.589 & 0 & 4.668 & 943.030 .300 & 1.067 .825 .500 & 29.24 & 1.271 .867 .500 & 81.53. \\
\hline
\end{tabular}

Source: Baznas Sorong City, 2015. 
Above data shows that, in 2014, zakat fund growth at average 10.65\%, zakat mal 33.72\% and Infaq/Shadaqah 37.15\%. In other words, for 3 years consecutive is $15.38 \%$ growth for infaq/shadaqah, $11.89 \%$ for zakat mal and $9.64 \%$ for zakat fitrah. Highest growth percentage is infaq/shadaah, followed by zakat mal (property) and zakat fitrah. If we refer to this condition, zakat body' contribution is only below infaq (common charity) level. Furthermore, if this situasion is continue, it is possible that zakat institution will encounter stagnant state, due to their failure to achieve their mission as Amil Zakat.

Back to the data given, from the number of structure types of income funds collected by BAZNAS, it is showed that zakat fitrah achieve $60.38 \%$, zakat mal $22.72 \%$ and infaq/shadaqah $16.46 \%$. The Growth zakat mal collection is considered still at low level, it is seem to be there is a connection between the nomads' zakat duties behaviour and the distribution of their zakat. Although there is no specific amount of nomad' zakat that has been distributed on certain mechanism by BAZNAS, it is undeniable fact that the income structure of Sorong City is driven by the nomads.

Meanwhile, moslem residents in Sorong City still have the opportunity to receive their zakat (Asnaf) as generally stated, the the human development index of Sorong people is still at concern. They also have tendency to counting on their consumption to the nature (Stepanus Malak, 2014). Therefore, some of the BAZNAS program needs fund aids from the Moslem including the nimads in Sorong City.

\section{Research Problem}

In this study we have some research problem related to behavior of Nomads in paying zakah in Sorong city, they are:

- Is the behavior of the nomads in meeting zakat duties in Sorong City is happened distribute zakat fairly so that this attitude will support zakat collection through BAZNAS Sorong City?

- Is the zakat dutys knowledge sufficiency amongst nomads support the fairness of zakat distribution?

- Is the attitude of nomads in Sorong City support the zakat distribution fairly?

- Is the deed of nomads in Sorong City support the zakat distribution fairly

\section{Theoretical Foundation: A Review}

Journey in searching of nomads (muzzaki) reference writings, we have found: First. (Wahbah az-Zuhaely, 1989) transferring zakat from one place to another place is justified as long as that place is need zakat (Wahbah az-Zuhaely, 1989:892). Second, zakat law is pointed to workplace as mentioned by al-Sarkhasiy w: 1062 M. According to him, if there is a Moslem lived in dar harb and owned wealth in dar Islam is eligible for zakat, therefore, the government should take cares his zakat in dar Islam (as-Sarkhasiy, ).

Differently with this study, above description is based on figh, this study rely on Islamic Economic perspective. Nevertheless, some of Islamic scholar's opinion about zakat transfer from workplace especially Shafi'i school is one of theory used in this study. In understanding the issues payment behavior, we should describe some terms related as below:

\subsection{In sight of Muzakki or Zakat Payer behavior}

According to Benjamin, an education psychologist, as stated by Kosasih, devided 3 behaviours; they are knowledge, attitude and action (Benjamin Bloom, 1856). These three aspects will carry competency (E. Kosasih, 2014). Corellate with attitude is regarded, as willingness is Islamic knowledge tradition. Al Ghazali said that willingne is built by two elements; knowledge and deeds (Al Ghazali, 1985). Again, knowledge has syarth function (ashluhu wa syarthuhu) as the base and provision while deeds is the results or impact/tsamratuh (Al Ghazali, 1985). Asy-Suyuthi, an expertise in Islamic Law Methodology (Ushul Figh) discussed furthermore in his book. Moreover his discussing about the human intention (willingness), he also mention about doubtness (asy-syak). Based on his opinion, in Islamic Law view the one's doutbness, will not drive one to commit something legally - al-Ashlu fi Asy syakki ka adam al-Fi'l (Al-Suyuthi, 1983).

Relevancy of behavioral theory proposed by Bloom and al-Ghazali et all, Zakat in Islam is considered as ibadah (good deeds) of wealth that moslem (Muzzaki) should exert.

The other term is Moslem whom legally firmed to exert zakat (Muhammad Ali Samiran, undate, : 1). This term has been applied to residents (muqim) or nomads Muhammad (Al-Hashkafy, 1965). As the deed of wealth, the action when Muzzaki difference their wealth through the accredited mechanism, regarded as economic activities. An economic activity in economic theory known as consumer behaviour as Sadono has stated that consumer behavior has thought us that, if someone's utility is increasing, it is mean the value of something (good) is also increase (Sadono Sukirno, 2012).

According to Mowen, during 1970 and 1980, the consumer behavior is considered as judgment bystander. 
Moreover, he found that, customer faced difficulties in determining their needs. Decision would be made based on experiences, desire and economy (John C. Mowen, 2002).

\subsection{Zakat Distribution}

The word distribution came from word distribute, that can be define by several meanings; spread, chain, supply, dispense, disburse, allocate. The root of distribution is allocation and division. Distribution means the way to process how to distribute. Zakat distribution is to deliver zakat fund from Muzzaki to Mustahik (zakat recipients). This study is focusing on nomads' attitude towards their zakat duties through BAZNAS Sorong City. In Islamic treasury especially related to zakat distribution, Syafii has mentioned in kitab al-ulm, that zakat delivered too his neigbour (Arabic: jar) is allowed as long as the zakat demand in that area is accommodated. Furthermore, if someone lived a far away from his properties, then the distribution of his zakat should be done in where the property is located. Hence, a farmer can distribute his zakat to his neighbour or another neighbour (M. Idris Syafii, 1972).

\subsection{Fairness and Income Redistribution Perspective}

The word "fair" in Indonesian language has three aspects; same weight, stand a side with the true, non-arbitrary. The concept of fairness itself should elaborate those 3 aspects mentioned above. Accroding to al-Maraghi as stated by Abdul Muin Salim, fairness or justice contains the definition of someone's rights establishment and fulfillment which is he granted to. Moreover, he said that justice has been interpreted as proportional (Salim: 1995).

\subsection{Income Redistribution}

The term of redistribution policy according to Todaro means a policy for income equality to promote development. In economy theory, we use tax instrument to help the underprivileged and for village development (Todaro: 1985). Zakat is one of income redistribution form, as stated by Hamzah. He comprehend that principles developed by zakat distribution is income redistribution form muzzakki (zakat obligator) to mustahik (zakat recipients) in the same region. This principle has common action with Muadz bin Jabal, he is zakat collector in prophet Muhammad PBUH era (Hamzah, 2009).

\section{Construction Theory and Modelling of Nomads Behavior}

The theory of (Syafi'i, 1972) about zakat distribution correlated with consumer behavior theory proposed by (Mowen: 2002). Both theories showed that Muzzaki' (nomads) zakat distribution affected by 3 aspects, there are; knowledge, attitude and behavior. The first two aspects related with consumer behavior theory and functionally linked. The two aspects also linked with two aspects of consumer behavior theory, which is action and consideration aspect. Eventually, action aspect has the common theory with consumer theory. In other words, zakat distribution by the nomads can be classified as consumer behaviour. From the consumer behavior perspective, before the nomads undertake they zakat duties, they preceed with consideration first. The consideration covered the location of zakat distribution; either the distribution should be done in their origin or their work location (BAZNAS in Sorong City). In addition, this type of zakat fund can be categorized as a variable cost in order to buy s service, ie an attemption for nomads to deserved Allah SWT' blessing, they worship Allah by doing good deeds in wealth.

\section{Fairness Instrument Formulation}

\subsection{Determination of Counterweight}

This study is using $50 \%$ as counterweight benchmark to define their benhaviour tendency. Assuming this benchmark could give a better stationary chance in choosing whether to distribute zakat to their origin or to BAZNAS in Sorong City. This overvie is inspired by Imam Syafii who has proposed that zakat distribution should prioritize to work location rather than outside.

\subsection{Fairness Percentage Level}

When using Imam Syafii' theory in a percentage level, it shows that nomads behavior should give percentage $>50 \%$ to 
work place. By looking fron nominal implication view, it shows the higher percentage of zakat in work place, the more fairness level is reached, and otherwise $<50 \%$ will describe a low level of fairness of zakat distribution.

\subsection{Nomads (Muzzaki) Fairmess Behaviour Category}

Using the formula of zakat distribution below:

Fair $=D Z>50 \% T$

Unfair $=\mathrm{DZ}<50 \% \mathrm{~T}$

Description:

DZ Zakat Distribution

T Workplace

Stationary State

\subsection{Determination Fairness Scale}

Fairness scale is defined as below:

$$
\begin{array}{ll}
\text { 80-90 } & \text { Most Fair } \\
70-79 & \text { Fair }
\end{array}
$$

51-69 Less Fair

90 is the maximum level to represent fairness action. 10 are to represent distribution in origin. The argument is, fairness should be build by considering the rights of origin. The reason we give 10 to represent the rights of fairness scale, is because 100 shows fairness level of deviation due to failure to fulfill the rights.

Unfairnes scale is defined as below:

40-50 Less Fair

30-49 Unfair

1-29 Most Unfair

\section{Research Finding}

\subsection{The Reality of knowledge level of Nomad}

Data given on table below is the percentage of the reason behind the willingness of nomads to pay zakat.

Table 2. Reason of Zakat Payment Location

\begin{tabular}{|c|l|c|}
\hline No & Item & Percentage \\
\hline 1 & Religion Understanding & 72.41 \\
\hline 2 & Family relationship & 20.68 \\
\hline & Jumlah & 93.09 \\
\hline
\end{tabular}

Source: Primary data, 2015.

Refer to the table; religion understanding is prominent rather than family relationship. The implication of the data presented is the nomads have strong religion foundation when they have to choose zakat payment location. The strong faith is the basic reason to pay zakat supported by data below:

Table 3. Reasons of Paying Zakat

\begin{tabular}{|c|l|c|}
\hline No & Item & Percentage \\
\hline 1 & Obeying Allah' Command & 89.65 \\
\hline 2 & Afraid of scourge & 3.44. \\
\hline 3 & Ashamed of Neigbour & 0 \\
\hline 4 & No Answer & 6.89 \\
\hline & Total & 100 \\
\hline
\end{tabular}

Source: Primary data, 2015. 
The data shows that implementing Allah's command (89.65) or (90\%) implicates that there is very significant relation between zakat devotion and the nomad's cognition of zakat

\subsection{Reality of Nomad's Zakat Behavior}

The reality of nomad's zakat behavior pictured as several tables below:

Table 4. Reasoning of Zakat Payment

\begin{tabular}{|c|l|c|}
\hline No & Item & Percentage \\
\hline 1 & Obeying Allah' Command & 89.65 \\
\hline 2 & Afraid of scourge & 3.44. \\
\hline 3 & Ashamed of Neigbour & 0 \\
\hline 4 & No Answer & 6.89 \\
\hline & Total & 100 \\
\hline
\end{tabular}

Source: Primary data, 2015.

In side of the religious (Islam) implementation level of Nomad, 89.65\% dominates their reasoning compared with the external factors of the religious impulse. The level of this religious compliance is relevant to the following table of zakat obedience. The level of their adherence or discipline reached $96.55 \%$, while those who undiscipline do not reach $4 \%$.

Table 5. Zakat Peyment Obedience

\begin{tabular}{|c|l|c|}
\hline No & Item & Percentage \\
\hline 1 & Obeyed Zakat payment & 96,55 \\
\hline 2 & Disobeyed & 0 \\
\hline 3 & Obeyed and Disobeyed & 3,44 \\
\hline & Total & 100 \\
\hline
\end{tabular}

Source: Primary data, 2015.

The level of zakat obedience from Nomad is reached high as $96,55 \%$ but this percentage if compared to their discipline to pay zakat in their workplace.

Table 6. Comparison between Zakat and Prayer

\begin{tabular}{|c|l|c|}
\hline No & Item & Percentage \\
\hline 1 & Paying Zakat is difficult & 0 \\
\hline 2 & Prayer more difficult than Zakat & 10,34 \\
\hline 3 & Both is Difficult & 0 \\
\hline 4 & Both is not difficult & 89,65 \\
\hline & Total & 100 \\
\hline
\end{tabular}

Source: Primary data, 2015.

\subsection{The Reality of Zakat Payers Behavior}

\subsubsection{The amount of Zakat}

The amount of Zakat which paid by Nomads can be seen in the table below 
Table 7. Amount of Zakat according to Payment Location

\begin{tabular}{|c|c|c|c|c|}
\hline No & Homeland payment & \% Zakat Payer & Payment in Sorong & \% Zakat Payer \\
\hline 01 & $100 \%$ & 10.34 & $100 \%$ & 55.17 \\
\hline 02 & $<50 \%$ & 6.89 & & \\
\hline 03 & $>50 \%$ & 13.79 & & \\
\hline
\end{tabular}

Source: Primary data, 2015.

The Table shows that, $55.17 \%$ Nomad Zakat payers in Sorong is 100\%, and the biggest percentage wether in side of payer or amount of Zakat fund. In side of zakat payment in their area of origin is various based on the percentage of amount of Zakat fund. For amount less than $50 \%$ of fund is around $6.89 \%$ while more than $50 \%$ of zakat fund is around $13.79 \%$.

\subsubsection{Zakat Payment Location}

In term of location, zakat behavior described in two sides; from the homeland of Nomad and from Location of Nomad's work:

\subsubsection{The Homeland of Nomad}

Table 8. Location of Zakat Payment

\begin{tabular}{|c|l|c|c|}
\hline No & Payment Location & \% Zakat Payer & Categorization \\
\hline 01 & The origin area & 13.79 & Static \\
\hline 02 & Sorong City & 6206 & Static \\
\hline 03 & Sometime in Sorong City or origin Area & 24.13 & Dynamic \\
\hline
\end{tabular}

Source: Primary data, 2015

From the data we can see that $13.79 \%$ paid Zakat in their origin area with payment percentage more than $50 \%$ of Zakat amount, and the rest tend to pay zakat in Sorong city. The factors why the nomads choose their homeland are: a). The masque administrator and orphanage in their homeland communicate actively with them. Every year the nomad received brosure and proposal related to Zakat payment. b). Desire to serve the homeland. The discourse of these two factors is tends to the first. This argument supported by that 20,68\% communication between nomad and homeland is fluently. This percentage is basically not indicates that the communication has big impact but in another side this opportunities not supported by the zakat administrator in sorong. The table below shows the reasoning of zakat payment location

Table 9. Reason to choose Zakat Payment Location

\begin{tabular}{|c|l|c|}
\hline No & Item & Percentage \\
\hline 1 & Religion Understanding & 72.41 \\
\hline 2 & Family relationship & 20.68 \\
\hline & Total & 93.09 \\
\hline
\end{tabular}

Source: Primary data, 2015

The table shown that family communication and relationship are main reason whay the nomads paid their zakat in homeland.

\subsubsection{Zakat in Workplace}

Zakat payment in Sorong city from nomad is only around $62,06 \%$, while those who has dynamic behavior reached 24 , $13 \%$. These data show the structure of behavior (attitude) zakat nomads in Sorong city is divided in three typologies. i.g. 
Constant in workplace, constant in hometown and dynamic typology, which is sometimes at workplace and sometimes at homeland. If these three typologies simplified in two, then known that $12,065 \%$ (as result of $50 \%$ from 24, $13 \%$ the data) is percentage a percentage that can be directed to the payment site to the workplace in Sorong and other in hometown. Hence, if this view is accepted means the zakat payment for hometown becomes $26.44 \%$. This percentage is result from addition of $26.44 \%$ with $12,065 \%$. The result considered as low compared to those who paid in Sorong Consistently.

\section{The Distributive Justice Aspect of Zakat for Workplace}

\subsection{The Percentage Level of Fairy}

Based on the data analysis found that there are two prototypes of Nomads Muzakki (Zakat payers) in Sorong, the constant and the dynamic. Constant is discipline to pay zakat in the workplace and dynamically interpreted as a form of behavior that is sometimes paying zakat in the workplace and sometime at home. Constant behavior as much as $62,06 \%$ and dynamic behavior reached 24, 13\%. In addition beside the above two prototypes, there is a third typology emerged, developed from dynamic category. That is, after dinamis category divided by $50 \%$ and added to the work place (Sorong) and the other $50 \%$ is added to the data in their hometown. On that basis, allows the minimum and maximum categories obtained on each of the two prototype

Based on description above, known that the Nomads payment of Zakat in Sorong City, the ranges is between 62 , $06 \%-74,125$ or $74,13 \%$. With regard to the minimum percentage of Zakat $(62,06)$ and $50 \%$ as a counterweight, then result obtained is $12,06 \%$. In other side the maximum percentage is $74,13 \%$ and after reduced by $50 \%$ as counterweight then obtained $24.13 \%$.

\subsection{Categorizing Justice Aspect of Nomads Muzakki Behavior}

The category of justice aspect of Nomads Muzakki behavior in Sorong City could be seenby using categorization formula to the data percentage of Zakat allocation in workplace.The data obtained are:

Data percentage:

Data minimum $62,06 \%$

Data maximum $74,13 \%$

Categorizing formula:

Fair $=\mathrm{DZ}>50 \% \mathrm{~T}$

Unfair $=\mathrm{DZ}<50 \%$

Based on the data above we can say that if minimum and maximum data percentage linked to categorization formula known the percentage of minimum data is bigger than counterweight number, as well as the maximum percentage data. This implicates that zakat payment of Nomad of Sorong city is fair in term of Zakat distribution..

\subsection{Fairy scale of Nomad Zakat}

The formula of fairy scale of Nomad zakat is:

80-90 most fair

70-79 Fair

51-69 less fair

The data of zakat percentage for distribution in Sorong city is minimum in $62,06 \%$ and maximum $74,13 \%$, therefore the data shows that the behavior of nomad in paying zakat is in fairy even in the lowest level.

\section{Theoretical Implications}

This research has emphasized the confinement of a new knowledge of Zakat which developed by Islamic economics. Zakat Economy development is imperative science today because: First, the needs of knowledge development especially in Zakat field. Second, contemporary, the problem of zakat not only linked with Islamic Law but also from ecomony aspect which is previously considered as one of economic variable in the macro context, especially in the effectiveness of wealth/zakat distribution. This study also would bring benefit to BAZNAS (Zakat Institution) Sorong City, Majelis Ulama Indonesia (Islamic Scholar Council of Indonesia) Sorong City, and others Islamic Organization. From this step, it is 
expected that will lead improvement into zakat management, either in fatwa or related to zakat obligator.

However, the weak communication is one of the causes of unequal zakat distribution, so theoretically this study supports the implications agency theory. According to the agency theory which popularized firstly by Jensen and Meckling shareholders in a company can convince himself about his ability to control the optimal management decisions in accordance with their wishes. This can be done as long as they can perform intensive provision of adequate cover in supervision and profits sharing outside salary such as bonus. The supervision is dealing with auditing financial statements and reviewing the work of management systematically (James C et al., 1997). Based on this theory, Baznas of Sorong City can manage intensively in order to establish communication with nomad group.

\section{Conclusion}

The behavior of Muzakki nomads in Sorong categorized as fair behaviors when choosing a distribution of zakat between workplace (Sorong City) and hometown. This conclusion is based oni) Aspects of the knowledge, the majority or $72.41 \%$ of Muslim Nomads understood zakat as religious orders. This percentage of immigrants has shown that the knowledge has pushing in conducting the zakat in fairy behavior. ii) Zakat as obligatory aspect has motivated alms attitude of nomads. The $89.65 \%$ of nomads state that running the commands of God as the basis for consideration in paying zakat. iii zakat) Zakat obligatory action aspect nomads in Sorong support equitable distribution of zakat, although the figure of at least $62,06 \%$ and a maximum of $74.13 \%$, or on a scale that is less than fair.

\section{References}

Al-Gazali, Abu Hamid Muhammad ibn Muhammad, 1985, Ihya Ulumuddin, (Bairut: Dar Ma'rifah,Vol. IV)

Al-Sarkhasiy, Muhammad ibnu Ahmad ibnu Abi Sahl Syamsul Aimmah. 1374, al-Mabsuth, Kitab Zakat, in the Program of Maktabah AsySyamilah.

Al-Suyuti, Abdurrahman bin Abi bakar, 1983, al-Asybah Wan Nadhair, t.tp: Dar kitab Ilmiyah.

Al-Zuhaely, Wahbah, 1989, al-Figh al-Islamy wa Adillatuhu, Vol. II, Damaskus: Dar Fikr

Hamzah, 2013, Zakat Economy (Ekonomi Zakat), Makassar: Alauddin Press.

Hamzah, 2009, Empowerment of Amil Zakat at National Amil Zakat in Improving Society Welfare (Pendayagunaan Amil Zakat Pada Amil Zakat Nasional dalam Peningkatan Kesejahteraan Umat), Dissertasion, PPS UIN Jakarta.

Al-Hashkafy, Muhammad Alauddin ibn Ali, 1965, ad-Dar al-Mukhtar Syarh Tanwir al-Abshar Fi Fighi Mazhab Imam Abi Hanafiyah, Vol. II, Bairut: Dar Fikr.

Indonesia Big Dictonary (Kamus Besar Bahasa Indonesia) on Line, http// kbbi.web.id/ diakses tgl 6 Juni 2015.

Kosasih, E, 2014, the Strategy of Studying and Learning (Strategi Belajar dan Pembelajaran), Bandung: Yrama Widya.

Malak, Stepanus. 2014, The Transformation of Leadership in Papua (Transformasi Kepemimpinan di Papua), Bandung: Bejana.

Mowen, John C. 2002, Consumer Behavior, Translate by Lina Salim, (Jakarta: Erlangga).

Salim, Abdul Muin. 1995, Conception of the Power of Politic in Alquran (Konsepsi Kekuasaan Politik Dalam Alquran), Jakarta: Raja Grapindo.

Samiran, Muhammad Ali, undate, Atsar al-Iqtishadiyyah lizzakati, in the Program of Maktabah Asy-Syamilah.

Sukino, Sadono, 2012, Micro Economics (Mikro Ekonomi), Jakarta: Raja Grafindo.

Syafii, Muhammad ibn Idris. 1972, al-Um, Bab Jiran Ash-Shadaqah, Juz II, (Bairut: Darul Ma'rifah).

Todaro, Michael P. 1985, Economics for a deploving world, an introduction to principles, problems and policiesfor development, translated (Jakarta: Akademika Presindo)

Utami, Noor Azizah Rikanti, 2012, the Concept of Islamic Leaders of Sorong City in improving the Society Religious Understanding, in Society lecture and Diversity (Konsep Para Dai Kota Soring Dalam Meningkatkan Pemahaman Keagamaan Masyarakat, dalam Dakwah dan Keragaman Umat), Sorong, STAIN Sorong Press.

Van Home, James C., John M. Wachowicz, JR., 1997, the Prinsips of Financial Management (Prinsip-Prinsip Manajemen Keuangan), translated by Heru Sutojo, Jakarta: Salemba Empati. 